\title{
Effect of McConnell Patelar Taping on Joint Position Sense and Threshold to Detection Passive Motion in Sub acute Stroke Patient
}

\author{
Cokorda Gde Bayu ${ }^{1}$, Meisy Andriana ${ }^{2 a}$, Alit Pawana ${ }^{3}$ \\ ${ }^{a}$ Corresponding author: meisy1913@yahoo.com \\ ${ }^{1,2,3}$ Department of Physical Medicine and Rehabilitation, Faculty of Medicine Universitas Airlangga 60132, RSUD Dr. Soetomo, \\ Surabaya, Indonesia
}

\begin{abstract}
The purpose of this study is to analyse the effect of McConnell patellar taping on joint position sense and threshold to detection passive motion in sub acute stroke patient. This is an pre-post test analysis experimental study ( $\mathrm{n}=8$ ). The McConnell patelar taping placed on knee joint in paresis side for 30 minute with McConnell technique and measured by isokinetic dynamometer (Cybex). This research placed in Physical Medicine and Rehabilitation outpatient clinic Dr Soetomo General Hospital. Eight sub acute stroke patient in this study had average age 46.38 \pm 11.01 years old and onset of stroke 3,87 $\pm 1,13$ months. The result of McConnell patelar taping application showed significant increase of knee joint position sense in $15^{\circ}$ (from 10,78 $\pm 3,5$ to $12,22 \pm 3,64$ degree) , $30^{\circ}$ (from 23,17 $\pm 3,54$ to $24,27 \pm 3,50$ degree) and improve threshold to detection passive motion (from 13,09 $\pm 3,49$ to $12,09 \pm 3,51$ second ). Result of this study, conclude that application of McConnell patellar taping can increase joint position sense and improve threshold to detection passive motion and useful for improvement on proprioception in sub acute stroke patient.
\end{abstract}

Keywords: McConnell patellar taping, sub acute stroke, joint position sense, threshold to detection passive motion

\section{Introduction}

Stroke is the leading cause of disability in the world. Proprioceptive impairment in stroke patients is reported to occur in about $50 \%$ of patients. This disorder is often associated with postural instability, impaired motor healing, level of patient safety, length of stay in hospital, and decreased independency (Kenzie et al., 2014). Somatosensory disturbances (proprioceptive and tactile somatosensory) are more commonly affected in the lower extremities than the upper extremities in stroke patients, where this will increase in frequency with increasing level of weakness and stroke severity. Somatosensory disturbances in the lower extremities are a third important factor, which reduces walking speed in stroke patients. The incidence of falls in stroke is higher in people with somatosensory disorders compared to those without the disorder (Chia et al., 2019).

Patellar taping is a simple and efficient technique that is usually used to reduce symptoms in anterior knee pain and patelofemoral pain syndrome (PFPS). Patellar taping can improve proprioception of the knee (Mokhtarinia et al., 2008). Similar results were obtained in a study conducted by Callaghan and colleagues, patellar taping on PFPS increased proprioception (as assessed by JPS, both actively and passively), but this increase in proprioception only occurred in subjects who had impaired proprioception from the start (Callaghan et al., 2005). However, there are few studies on the addition of patellar taping as an adjunct therapy for proprioceptive function. Therefore, the researcher believes that it is necessary to conduct a study to assess the improvement of proprioceptive function in subacute stroke patients with the addition of McConnell patellar taping. 


\section{Materials and Methods}

This study is pre post test experimental study. Data collection was carried out from March to October 2020 in Physical Medicine and Rehabilitation outpatient clinic and Gait Analysis Laboratory of Physical Medicine and Rehabilitation Installation at RSUD Dr. Soetomo Surabaya. The inclusion criteria for patients were : first or recurrent stroke, subacute stroke (more than 2 weeks and less than 6 months),, spasticity of the ankle plantar flexor based on the Modified Asworth Scale $\leq 2$, can understand and follow simple verbal instructions, and signed a written informed consent prior to participation. The exclusion criteria were : Cognitive deficit (MMSE score < 24), neurological disorders other than stroke, heart problems, uncontrolled hypertension or severe pain, apraxia, range of motion limitation on ankle and knee joints, taping hypersensitivity

McConnell patellar taping is a rigid taping (Strappal, BSN) by the method performed (Shin., et al, 2014) by affixing to the knee joint that has been positioned and pulled medially (from the lateral kneecap to covering the medial end of the semitendinosus muscle), and used for 30 minutes.

Joint Position Sense (JPS) of the knee is the ability to sense the position of the knee joint, at angles of $15^{\circ}, 30^{\circ}$ and $60^{\circ}$ flexion, measured using an isokinetic dynamometer (Cybex NORM TM). Calculated the difference between the target angle and the angle of joint reposition (absolute error), in degrees (absolute error normal value: $2.5^{0}$ ).

The knee threshold to detect passive movement (TTDPM) is the time it takes for the subject to detect any movement of the knee joint generated by the isokinetic dynamometer (Cybex NORM ${ }^{\mathrm{TM}}$ ), with a speed of $1^{0}$ per second, in seconds (normal value for TTDPM: 2.5-4 seconds ).

The statistic in this study was performed using IBM SPSS program version 24, a statistical software. Compare before after application using taping using paired T-test. Significant if $\mathrm{p}<0,05$

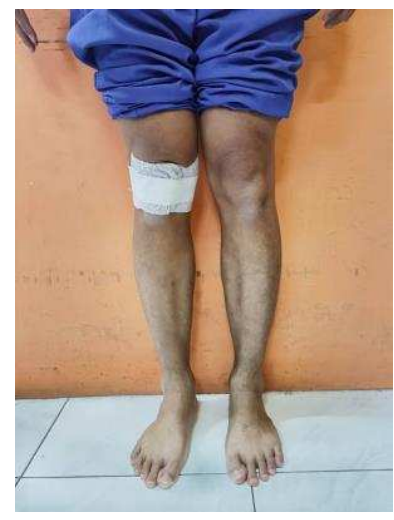

Figure 1. McConnell Patellar Taping

\section{Results and Discussion}

Total subjects were 8 patient. The mean onset of stroke was $3.87 \pm 1.13$ months (onset range 2-6 months). The mean age of subjects was $46.38 \pm 11.01$ years (with an age range of 30-57 years). The average body weight of the subjects was $60.12 \pm 9.91 \mathrm{~kg}$ (with a range of $48-78 \mathrm{~kg}$ ). The average height is $158.75 \pm$ $6.90 \mathrm{~cm}$ (with a height range of 150-170 cm). The mean body mass index of research subjects was $23.65 \pm 2.84$ $\mathrm{kg} / \mathrm{m} 2$ (with a body mass index range of $20.2-28.8 \mathrm{~kg} / \mathrm{m} 2$ ). The number of subjects who had non hemorrhagic stroke was 6 people (75\%), while the other 2 people had a hemorrhagic stroke (25\%). All subjects in this study 
were first attack stroke patients (100\%). Weakness on the right side of the body were 3 people $(37.5 \%)$, left side 5 people $(62.5 \%)$.

Table 1. Subject Characteristic

\begin{tabular}{lcccc}
\hline Characteristic & N & Min & Max & Rerata \pm SD \\
\hline Total Subject & 8 & & & \\
\hline Age (year) & & 30 & & $46.38 \pm 11.01$ \\
\hline Gender & & & & \\
\hline Men & $4(50 \%)$ & & 6 & \\
\hline Women & $4(50 \%)$ & 2 & 78 & $3.87 \pm 1.13$ \\
\hline Stroke Onset (months) & & 48 & 170 & $60.12 \pm 9.91$ \\
\hline Weight $(\mathrm{kg})$ & & 150 & 28,8 & $158.75 \pm 6.90$ \\
\hline Height $(\mathrm{m})$ & & 20,2 & $23.65 \pm 2.84$
\end{tabular}

Table 2. Stroke Characteristic

\begin{tabular}{lcc}
\hline & Frequency & Percentage \\
\hline Stroke type & 6 & \\
\hline Non Hemorrhagic & 2 & 75 \\
\hline Hemorrhagic & & 25 \\
\hline Paresis side & 3 & 37,5 \\
\hline Right & 5 & 62,5 \\
\hline Left & & \\
\hline Stroke attack & 8 & 100 \\
\hline $1^{\text {st }}$ attack & \\
\hline
\end{tabular}

Table 3 shows average JPS of all subjects before and 30 minutes after taping. It was found that the increase in paresis side JPS at $15^{0}$ was statistically significant $(\mathrm{p}=0.016)$ between before taping $(10.78 \pm 3.5)$ after being taped for 30 minutes $(12.22 \pm 3.64)$. At $30^{\circ}$, there was also an increase and was statistically significant $(\mathrm{p}=0.050)$ between before taping $(23.17 \pm 3.54)$ and after taping for 30 minutes $(24.27 \pm 3.50)$, while for JPS at $60^{\circ}$ no statistically significant results were obtained $(\mathrm{p}=0.622)$. 
Table 4 shows the mean TTDPM before and 30 minutes after taping. There was a decrease in TTDPM and statistically significant $(\mathrm{p}=0.001)$ between TTDPM before $(13.09 \pm 3.49)$ and TTDPM after taping (12.09 $\pm 3.51)$. The average TTDPM is $1 \pm 0.55$ seconds

Table 3. Average knee joint position sense (JPS) of the paresis side, before and after taping

\begin{tabular}{|l|l|l|l|c|}
\hline & $\begin{array}{l}\text { Before Taping } \\
\text { (degree) }\end{array}$ & $\begin{array}{l}\text { 30 minutes after } \\
\text { Taping (degree) }\end{array}$ & $\Delta$ Mean \pm SD & p value \\
\hline JPS 15 & $10,78 \pm 3,5$ & $12,22 \pm 3,64$ & $1,45 \pm 1,29$ & $0,016^{*}$ \\
\hline JPS 30 & $23,17 \pm 3,54$ & $24,27 \pm 3,50$ & $1,1 \pm 1,3$ & $0,050^{*}$ \\
\hline JPS 60 & $53,3 \pm 4,09$ & $52,2 \pm 7,39$ & $1,15 \pm 6,3$ & 0,622 \\
\hline
\end{tabular}

* Significant if $\mathrm{p}$ value $<0,05$

Table 4. Average knee threshold to detection passive motion (TTDPM) of the paresis side, before and after taping

\begin{tabular}{|l|l|l|l|l|}
\hline & $\begin{array}{l}\text { Before Taping } \\
\text { (second) }\end{array}$ & $\begin{array}{l}30 \text { minutes } \\
\text { after Taping } \\
\text { (second) }\end{array}$ & $\Delta$ Mean \pm SD & p value \\
\hline TTDPM & $13,09 \pm 3,49$ & $12,09 \pm 3,51$ & $1 \pm 0,55$ & $0,001^{*}$ \\
\hline
\end{tabular}

* Significant if $\mathrm{p}$ value $<0,05$

The results of the Joint Positional Sense (JPS) measurement of the knee at $15^{0}$ and $30^{\circ}$ increased when compared to the baseline and were statistically significant. Research by Mokhtarinia and colleagues, found the results of increased joint positional sense in patients with PFPS after being given patellar taping. Afferent receptors are present in the skin, ligaments, muscles and joint capsule and provide proprioceptive input to the knee joint. Although position sense receptors in joint capsules and ligaments are located deeper in the soft tissues and may be less affected by external support, patellar taping provides greater stimulation of skin and subcutaneous structures and increases pressure on underlying tissues. Receptors that also play a role are free nerve endings which react strongly to new stimuli and adapt quickly. Afferent signals from cutaneous receptors provide proprioceptive information and facilitate proprioception and muscular control by increasing the sensitivity and excitability of motor neurons. Another mechanism that may contribute to the increase in proprioception is the effect on the initial activity of the VMO muscle and changes in its recruitment threshold (Mokhtarinia et al., 2008).

McConnell patellar taping improves patella tracking in the patellofemoral groove by making the patella medial and this will cause patellar realignment (Shin et al., 2014). Realignment of the patella will change the leverage of the patella, maximizing the mechanical advantage of the quadriceps muscle. (Herrington, 2001). Shift or realignment of the patella to the medial direction can maintain the quadriceps muscle lever arm to be longer and ultimately cause an increase in the knee extensor moment and also increase the ability of the vastus 
medialis muscle to produce a greater knee extensor force (Crossley et al., 2000). Facilitation on muscle performance will increase proprioception through correction of afferent input from muscle receptors (Mokhtarinia et al., 2008).

Different results were obtained by Callaghan et al., where the use of patellar taping on the knee of PFPS patients, did not improve knee joint proprioception. However, after the study subjects were divided into normal proprioceptive groups ( $\leq 5$ degrees from the target angle) and proprioceptive disorders $(>5$ degrees from the target angle), proprioceptive improvements were found in patients with proprioceptive disorders after using patellar taping (Callagahan et al., 2002). In this study, the joint position sense increased only at $15^{\circ}$ and $30^{\circ}$ angles, while not at $60^{\circ}$ angles. This may be due to the anterior cruciate ligament. The ACL acts as a barrier to anterior movement of the tibia and exerts the greatest force at an angle of $15^{\circ}$ flexion and decreases to $90^{\circ}$ degrees of knee flexion (Dargel et al., 2007). When the ACL is stretched, there will be changes in the length and stretch of the ligament which will cause the capsuloligament mechanoreceptors contained in the ligament to provide and receive proprioceptive feedback (Nagai et al., 2011). It is this greater strain on the ACL at $15^{0}$ and $30^{\circ}$ flexion angles that may cause an increase in proprioception when compared to the $60^{\circ}$ angle.

The increase in joint position sense at $15^{\circ}$ and $30^{\circ}$ angles can also be explained by tension in the patellar tendon. Tension in this tendon is seen from the P/Q ratio (patellar tendon/quadriceps tendon force), which shows the force of the patellar tendon against the tibia. (Cleather et al., 2014). This P/Q ratio changes based on the knee flexion angle. At an angle $<45^{\circ}$, the ratio will be $>1$, while $<1$ if the knee angle is $>45^{0}$ (Dan et al., 2018). At an angle of $90^{\circ}$ and $60^{\circ}$ flexion is the optimal angle of contact of the patella to the femur, while at an angle of $20^{\circ}-30^{\circ}$ at the end of extension, the patella loses mechanical contact with the intercondylar groove (Neumann, 2010). Loss of patellar contact with the intercondylar groove of the femur may also contribute to the increased proprioception of the knee joint after patellar taping. McConnell patellar taping improves patella tracking in the patellofemoral groove. (Shin et al., 2014). The angle of $60^{\circ}$ is the optimal angle of contact of the patella to the femur, therefore there is no increase in proprioceptive after McConnnell patellar taping.

The results of the TTDPM measurement showed an improvement in the TTDPM of the knee joint after the use of patellar taping. There was a decrease in TTDPM and was statistically significant, from $13.09 \pm 3.49$ seconds to $12.09 \pm 3.51$ seconds. This result is different from the study conducted by Mokhtarinia and colleagues, where in PFPS patients who were given patellar taping, there was no improvement in the results of the knee joint TTDPM. Improvement was only found in the reproduction of an active angle of 20 degrees of the knee joint. (Mokhtarinia et al., 2012). The use of patellar taping can change the response of the brain. Research on the effect of patellar taping on brain activity during a knee joint proprioceptive test was carried out using fMRI (Functional Magnetic Resonance Imaging). The use of fMRI was carried out to measure BOLD (Blood Oxygenation Level-Dependent) which reflects the loss of oxygen from hemoglobin which causes iron to be paramagnetic. When a movement is carried out there will be neuronal activity and will increase oxygen consumption. Patellar taping increased the BOLD response in several areas (primary sensorimotor cortex and primary sensory cortex) compared to the knee joint without taping. This response shows that the effectiveness of using patellar taping not only provides mechanical support to the patella and changes in the biomechanics of the lower limbs, but also affects the brain (Callaghan, 2012).

\section{Conclusion}

Application of McConnell patellar taping on the paresis side of the knee in sub acute stroke patient for 30 minutes, increased joint position sense in $15^{\circ}, 30^{\circ}$ and improve threshold to detection passive motion. This application thought be useful for sub acute stroke patient for improvement on knee proprioception. Further research is needed to evaluate long term effect of McConnell patellar taping in stroke patient 


\section{References}

Abbas G and Diss C, 2011. Patellar tracking during the gait cycle. Journal of Orthopaedic Surgery, p 288-291.

Abulhasan J and Grey M, 2017. Anatomy and physiology of knee stability. Journal of functional morphology and kinesiology.

Afonso M, 2015. Modelling the Gait of Healthy and Post-Stroke Individual.

Beyaert C, Vasa R and Frykberg G, 2015. Gait post stroke : Pathophysiology and rehabilitation strategies. Clinical Neurophysiology, p: 335-355.

Callaghan M, McKie S, Richardson P and Oldham J, 2012. Effect of patellar taping on brain activity during knee joint proprioception test using functional magnetic resonance imaging. Journal of Physical therapy, vol 92, p 821-830.

Callaghan M, Selfe J, McHenry A and Oldham J, 2005. Effect of patellar taping on knee joint proprioception in patient with patellofemoral pain syndrome. Journal of Manual Therapy, vol 13, p 192-199

Chae SH, Kim YL and Lee SM, 2017. Effect of phase proprioceptive training pn balance in patient with chronic stroke. The Journal of Physical Therapy Science, p 839-44

Chia F, Kuys S amd Choy NL, 2019. Sensory retraining of the leg after stroke: systematic review and metaanalysis. Clinical Rehabiliatation, vol 33, p 964-979

Coupland AP, Thapar A, Qureshi MI, Jenkins H, and Davies AH, 2017. The Definition of Stroke. Journal of The Royal Society of Medicine, Volume 110, p: 9-12.

Cleather DJ, Southgate DF, and Bull AM, 2014. On the role of the patella, ACL and joit contact force in the extension of the knee. PLOS one.

Crossley K, Cowan S, Bennel KL, and McConnell J, 2000. Patellar taping : is clinical success supported by scientific evidence?. Harcourt publishers Ltd.

Dan M, Parr W, Broe D, Cross M, Walsh WR, 2018. Biomechanics of the knee extensor mechanism and its relationship to patella tendinopathy : a review. Journal of Orthopedic Research. P 3105-3112.

Dargel J, Gotter M, Mader K, Pennig D, Koebke J amd Wiethoff R, 2007. Biomechanics of the anterior crutiate ligament and implications for surgical reconstruction.

Flandry F and Hommel G, 2011. Normal anatomy and biomechanics of the knee. Sports Med Arthrosc Rev , vol 19, p: 82-92.

Gillen G, 2016. Stroke Rehabilitation : A Function-Based Approach, Fourth Edition. Elvesier inc

Gulati A, Mcelrath C, Wadhwa V, Shah J, Shah JP and Chhabra A, 2018 . Current clinical, radiological and treatment perspectives of patellofemoral pain syndrome. British Institute of Radiology.

Han J, Waddington G, Adams R, Anson J and Liu Y, 2016. Assessing proprioception : A critical review of methods. Journal of Sport and Health Science, vol 5, p: 80-90

Harvey RL, 2011. Stroke syndrome. In Braddom, RL: Physical medicine \& Rehabilitation. 4th ed, Philadelphia: Elsevier Saunders.

Herrington L, 2001. The effect of patellar taping on quadriceps peak torque and perceived pain : preliminary study. Physical therapy in sport. P 23-28

Jimenez MC, 2017. Normal Changes in Gait and Mobility Problems in the Elderly. Phys Med Rehabil Clin N Am 28, p 713-725.

Kenzie A, Semrau J, Findlater S, Herter T, Hill M, Scott S and Dukelow S, 2014. Anatomical correlates of proprioceptive impairments following acute stroke : A case series. Journal of the Neurological Sciences, vol 342, p: 52-61. 
Kharb A, Saini V, Jain YK, and Dhiman S, 2011. A Review of Gait Cycle and Its Parameters. International Journal of Computational Engineering \& Management, p: 78-83

Kim HY, Kim KJ, Yang DS, Jeung SW, Choi HG, and Choy WS, 2015. Screw-home movement of tibiofemoral joint during normal gait: three-dimensional analysis. Clinic in orthopedic surgery, vol 7, pp 303-309.

Lan T, Lin W, Jiang C, and Chiang H, 2010. Immediate effect and predictors of effectiveness of taping for patellofemoral pain syndrome. The American Journal of Sport Medicine, Vol. 38, p : 1626-1630.

Leibbrandt D and Louw Q, 2015. The use McConnell taping to correct abnormal biomechanics and muscle activation pattern in subject with anterior knee pain : a systematic review. The Society of physical therapy science.

Li S, Franscisco G, and Zhou P, 2018. Post-Stroke Hemiplegic Gait : New Perspectiveand Insights. Frontiers in physiology, Volume 9.

Loudon K, 2016. Biomechanics and pathomechanics of the patellofemoral joint. The International Journal of Sports Physical Therapy, vol 11, p: 820-8

McGee S, 2018. Evidence-based physical diagnosis. Elvesier inc , $4^{\text {th }}$ edition, p: 45-58.

Mokhtarinia H, Ebrahimi_Takamjani I, Salavati M, Giharpay S and Khosravi A, 2008. The effect of patellar taping on knee joint proprioception in patint with patellofemoral pain syndrome. Acta Medica Iranica, vol 46, p : 183-90

Nagai T, Sell TC, Abt JP, and Lephart SM, 2012. Reliability, precision and gender differences in knee internal/external rotation proprioception measurements. Physical therapy in sport. P 233-237

Neumann D, 2010. Kinesiology of the musculoskeletal system. Mosby Elvesier, $2^{\text {nd }}$ edition, p: 520-554.

Ovbiagele B and Nguyen-Huynh M, 2011. Stroke Epidemiology : advancing our understanding of disesase mechanism and therapy. The journal of the American society for experimental NeuroTherapeutics.

Pfeiffer P, DeBeliso M, Shea K, Kelley L, Irmischer B, and Harris C, 2004. Kinematic MRI assessment of McConnell taping before and after exercise. The American Journal of Sport Medicine, vol. $32, \mathrm{p}$ : 621-628.

Ratnawati A, 2014. Panduan Rehabilitasi Stroke. PERDOSRI, pp. 8-32.

Riemann B and Lephart S, 2002. The sensorimotor system, part II : The role of proprioception in motor control and functional joint stability. Journal of Athletic Training, vol 37, p 80-84

Riskesdas, 2018. Riset Kesehatan Dasar. Jakarta: Badan Penelitian dan Pengembangan Kesehatan Kementerian Kesehatan RI.

Roijezon U, Clark N and Treleaven J, 2014. Proprioception in musculoskeletal rehabilitation. Part 1: Basic science and principles of assessment and clinical interventions. Manual Therapy vol 20, p : 368-377

Shelburne KB, Torry MR, and Pandy MG, 2005. Muscle, ligament, and joint-contact forces at the knee during walking, in Medicine and science in sports and exercise, American college of sport medicine, pp 19481956

Shin J, Mun M, and Chung Y, 2014. The immediate effect of patellar taping on balance and gait ability in individuals with chronic stroke. Pysical Therapy Rehabilitation Science.

Kessner S, Schlemm E, Cheng B, Bingel U, Fiehler J, Gerloff C and Thomalla G, 2019. Somatosensory deficits after ischemic stroke : time course and association with infarct location. American Heart Association, p1116-1123

Song C, Lin J, Jan M, and Lin Y, 2011. The role of patellar alignment and tracking in vivo : the potential mechanism of patellofemoral pain syndrome. Physical therapy in sport, p: 140-147. 
Stein J and Brandstater M, 2010. Stroke Rehabilitation. Delisa 's Physical Medicine \& Rehabilitation, p: 551553

Stewart TD and Hall RM, 2006. Basic biomechanics of human joints: hips, knees and the spine, Current Orthopaedics, vol. 20, pp 23-31.

Taylor J. 2009. Propioception. Prince of Wales Medical Research Institue.

Whittle MW, 2007. Gait Analysis: an introduction. $4^{\text {th }}$ ed. , Butterworth Heinemann, pp.223-4.

Woolley S, 2001. Characteristics of Gait in Hemiplegia. Topic Stroke Rehabilitation, p: 1-18

Zorowits RD, 2010. Stroke. In: Cuccurullo SJ: Physical Medicine and Rehabilitation Board Review. 2nd ed. New York: Demos medical, pp. 40-87. 